\title{
COLD HEART
}

Communication is key.

\section{BY VICTORIA DIXON}

$\mathrm{I}$ taste ozoned rain, electrified metal and blood. It's cold. I'm close to hibernation. One tentacle throbs.

The spaceship lies in pieces and Imala is gone. I unbuckle my harness, yank exposed cords loose and fashion a sling, aching as I crawl from the wreckage.

Trees and grass burn despite the rain, and grey light reveals our wake of brutalized forest.

I cannot see my beloved, but send warmth to touch her.

There is nothing to touch.

Scorching despair ignites ship debris, and worse. Humans came to help. I try to quell my anguish and save them, but it's too late.

My rescuers ignite like walking saplings, shrieking. What have I done? They disintegrate. I can do nothing for our agony.

More of them hide until the fires die. Perhaps they hope I'll perish, but my people are born of heat. Cold is our anathema. I waver in and out of hibernation when they return in protective suits.

"Don't touch it!" a helmet-distorted voice says. They use machines to scoop up my body.

I do not blame them, but their distance is a cold anaesthesia. I wake in a laboratory.

"It's moving again," one man says. "Drop the temperature another degree." They heal my torn flesh while I sleep and mourn.

This is not kindness. It may be torture. I do not care. I have killed and deserve my fate.

They imprison me in a glass cell surrounded by tiers of oppressive black metal and unblinking lights. The door above is a series of metal panels and locks.

I wake from hibernation periods and onesided studies with puncture wounds until at last, humans try to communicate. Our gestures are meaningless to one another. They bombard me with sounds that make my heart jump, but my people do not make sounds. We share warmth. Sometimes light.

However, fluorescent communications are involuntary, private conversations between family members. I cannot make myself change a single cell colour.

I try to share my warmth, but they must believe my grief was an attack. My temperature spikes and coolant flows into my cell. When I awake, those scientists are gone.

During my incarceration, 15 people have watched and studied me. Two left an impression. Of those, one remains. George,

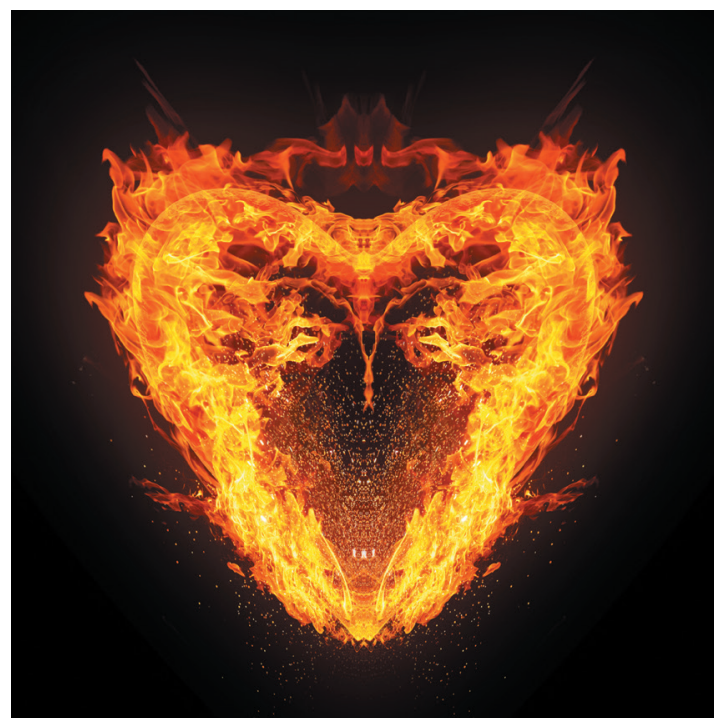

one steps beyond it without placing me in hibernation.

I long for friendship. Warmth. Family. Years pass and George hates me more than ever. I understand this. I loathed myself after the crash. It was my idea to study humans - my fault Imala died. My fault Halia was fired.

"You're dead." George’s face, once narrow, now overflows his white collar. His hair has thinned, but he remains the boy I remember. "They think you're dead. They won't rescue you."

I gather warmth. "I know."

"No one else knows you exist." George steps on Halia's yellow line.

I form warmth into words and impress Halia's beauty and kindness on his thoughts. "I loved her, too. I will never hurt you." Love is a warmth I know we can share. If he'll let me.

whose hair when he was younger appeared to combust into shocks of red and gold, never comes close. But long ago, he followed Halia like I used to drink Imala's warmth.

Halia - the only Terran who ever approached without fear.

Just once.

She stared at me, her head cocked. One lock of brown hair caressed her cheek. "It doesn't look healthy."

I had landed the year before. Their language was still strange. I will never speak as they do, but by then, I understood meanings and some nuances. I understood 'It'. Names encourage friendship and warmth; things I would never know again. So I thought.

"Do you need anything?" she asked.

Caring enough to ask was more sustenance than all their protein and vegetables.

"What is your name?"

She stepped close enough for me to tell her everything. I summoned warmth from my extremities.

George pulled her from the room, pointing out my elevated heart rate and temperature. White-faced caretakers sent me into hibernation for two days. When I awoke, George glared at me with red-rimmed eyes.

They fired her. This is one of their strange phrases. To me, this implies warmth and light, but to them? I hope it doesn't mean

ONATURE.COM Follow Futures: y @NatureFutures $f$ go.nature.com/mtoodm they killed her.

Now there's a bright yellow line on the floor where she turned back, and no
Water fills his eyes.

"Did you hear me?" He is so close. Like Halia in her extraordinary act of kindness. But as much as I love him, I know George is not kind. Not like her.

"You're dead and buried. No one's gonna find a body." He jabs the coolant button. I hibernate. When I wake, George is gone. I am not alone, but abandoned.

Days pass before they return. My heart rate and temperature ping warning sounds.

George and Halia. The years were kinder to her, but he still follows her with questions in his eyes.

I loved her too. I will never hurt you.

He'd heard me. Understood me in a mix of warmth and words that would have awed Imala.

The communications team enters. They connect new instruments to the temperature gauges. Joy and heat overflow. I fluoresce brilliant greens and vermilions. Blaze into colours invisible to the human eye.

My jailers protected themselves and I've never blamed them. Did they fear my anger, or that I might touch their cold hearts and reveal that I'm more than a thing?

My friends, my captors. They are all I have, but were never family.

Until today.

Halia takes George's hand and sobs. "He's beautiful." -

Victoria Dixon is obsessed with writing, culture, books, faith and family, although not in that order. She lives in Kansas, which is not monochrome, regardless of what fraudulent wizards might suggest. 